\title{
LEVELING THE UNLEVELED?
}

Syariah Advocates' Struggle for Equality in Indonesian Legal Pluralism

\section{Ratno Lukito ${ }^{1}$}

The Faculty of Syariah and Law, State Islamic University Sunan Kalijaga

Yogyakarta; Postdoctoral Research Fellow of SPIN-KNAW, Van Vollenhoven

Institute, Faculty of Law, Leiden University, the Netherlands (2009-2011)

\begin{abstract}
One of the ongoing problems faced by many Syariah advocates in Indonesia is how they can maintain their important role in the practice of law in the midst of the domination of common advocates. They are always trapped in double burden in concern of their position. On one side, they are challenged with the long historical inequality of educational access between religious (Islamic) groups and secular groups, while on the other, they have to deal with the problem of being part of Muslim society with a legal culture where Islamic law is commonly viewed as irreconcilable with secular legal traditions. This paper specifically discusses the role played by the Association of Indonesian Syariah Advocates (Asosiasi Pengacara Syariah Indonesia, APSI) in their struggle to assert equality between Syariah advocates and common advocates. It shows that although APSI has successfully attracted attention from the state and public in general, the interest shown by Syariah faculties remains even relatively low. Embedded traditional culture of studying Islamic law in many Syariah faculties seems to have influenced their attention towards APSI. Yet, with inclusive approaches in expanding the institution, APSI
\end{abstract}

${ }^{1}$ Financial support of this research was provided by the Royal Netherlands Academy of Arts and Sciences (KNAW). I thank to Prof. Jan Michiel Otto and Dr. Adriaan Bedner (VVI, the Netherlands) for their useful comments and suggestions. Any mistakes are however solely the responsibility of the author. 
can attract many advocates, not only from Muslim law graduates but from those of non-Muslims as well.

Keywords: Syariah Lawyers, APSI, Legal Pluralism

\section{A. Introduction}

It is indubitable that law plays a significant role in social change. Likewise, there can be little doubt that legal advocates are among the contributors to the reformation of social order and movements of social change. ${ }^{2}$ Many of the intricacies of social organization are successfully handled thanks to the attentiveness of legal advocates in dealing with criticism, protest, representation, scrutiny, etc. ${ }^{3}$ This is also true in a country such as Indonesia, where the application of the ideology of legal modernism runs in conjunction with the program of the country's development, so that advocates have maintained their involvement in resolving many of the problems of social organization.

In the case of Indonesia, one of the main questions is how advocates and lawyers in general can maintain their important role in the practice of law where the situation of legal pluralism does not always

${ }^{2}$ Discussions about the role played by lawyers in many social movements can be seen, for example, in J. M. Otto, "Jurists, Nation Building, and Social Tensions in Egypt," in B. Galjart and P. Silva (eds), Designers of Development: Intellectuals and Technocrats in the Third World (Leiden: CNWS, 1995), pp. 107-128; Richard L. Abel, "Lawyers and the Power of Change," Law and Policy 7 (1985): 5; Orly Lobel, “The Renew Deal," Minnesota Law Review 89 (2004): 342; Austin Sarat and Stuart A. Scheingold, Cause Lawyers and Social Movements (Stanford, California: Stanford University Press, 2006).

3 A. Kenneth Pye, "The Role of Legal Services in the Antipoverty Program," Law and Cotemporary Problems 31, 1 (1966): 211; in the case of the role of Muslim legal professional in a Western society, see Ra'ouf M. Abdullah, "Can a Person be a Believer and a Secular Government Lawyer Too?” Journal of Islamic Law and Culture 4 (1999): 11; Irshad Abdal Haq and Qadir Abdal Haq, "Community-Based Arbitration as a Vehicle for Implementing Islamic Law in the United States," Journal of Islamic Law and Culture 61 (1996): 61; Ijaz Chaudhry, "Choosing Law as a Profession: the Role of Muslim Attorneys," Journal of Islamic Law and Culture 4 (1999): 21; Irshad Abdal Haqq, Esq, "The Role of the Muslim Lawyer in Establishing Islamic Community Life," Journal of Islamic Law and Culture 3 (1998): 105; Kamran Memon, "A Survey of Muslims in the Legal Profession," Journal of Islamic Law and Culture 2 (1997): 121; Ijaz Manzoor Chaudhry, "The Shura Law Center, Inc.: A Community-based Islamic Legal Service," Journal of Islamic Law and Culture 1 (1996): 237. 
run parallel with the development of national law of the country. Here, the advocate is believed to always try to set up an equilibrium between the fact of legal pluralism existing in the society on the one hand and the programs of legal modernism and uniformism set forth by the state, on the other hand. In this paper, the focus will be given to analyzing the role played by Syariah advocates (i.e., advocates graduated from Syariah faculties) in Indonesia in setting such equilibrium. Social and political dimensions of the country have often made legal uniformism the preference in national law building, resulting in the development of the country's legal system independent from the different legal traditions living in society. As advocates of one unique legal apparatus, Syariah advocates individually as well as a profession must have been affected by such conditions, so that their efforts in dealing with that complicated situation certainly merit analysis. ${ }^{4}$

This paper will specifically discuss the role played by the Association of Indonesian Syariah Advocates (Asosiasi Pengacara Syariah Indonesia, APSI) in their struggle to assert equality between Syariah advocates and common advocates (those graduated from the faculty of law). In Indonesia, the issue of Syariah advocates has always centered on the debate whether they can really fulfill the requirement to become a qualified advocate. This is in fact just a reflection of the old political debate in the country on the place of Islamic legal institutions in the framework of national (secular) law. In other words, the distrust of most national lawyers to the quality of Syariah advocates is the result of their hesitation concerning the application of Islamic law in the country. Although the case has in fact been resolved with the promulgation of the Law No. 18 of 2003, according to which the equality of Syariah advocates is now recognized, how the struggle to reach such equality was

${ }^{4}$ Not much has been done on the study of the role of Syariah lawyers in a society where Islamic law is one of the dominant legal traditions therein. This might be the result of the prevailing studies on the subject which still in many respects disregard the role of lawyers in the process of Islamic legal practice, especially in an era of the modern nation state in which Islamic law should co-exist with other legal traditions. One of the few examples here can be found in Oba's article discussing the challenges faced by Muslim lawyers in Nigeria. See in Abdulmumini A. Oba, "Lawyers, Legal Education and the Syariah Courts in Nigeria," Journal of Legal Pluralism and Unofficial Law 49 (2004): 113. 
undertaken and some substantive problems involved in the issue are still valuable for discussion. In this case, the issue will be analyzed using the framework of legal pluralism idealized to be used as a premise in building national law, especially in relation to the current phenomenon of Islamic legal institutions existing in the milieu of the country's legal pluralism.

\section{B. Historical Impasse}

The pros and cons whether Syariah advocates can really be equal to common advocates have in fact never been separate from the long debate in the country on the quality of legal studies undertaken in the faculty of Syariah. As one might have realized, the educational system in Indonesia maintains the old "double roof" system in which not only the Ministry of National Education but also the Ministry of Religious Affairs govern all activities related to education in the country. ${ }^{5}$ Although many may see that such a system results in intricate problems of educational management, the political decision seems factually to come to the fore. It is indeed an issue more governed by political factors than managerial matters since, seen from many perspectives, the double system policy will not help solve the country's complicated problems of education. One of the obvious consequences here is the high cost of the system, besides the complexity of the other more substantive issues such as those related to the division of subject matters taught in each institution.

Indeed, one of the main considerations taken in the policy of a double roof system is related to the position of religious education in the country. The principle of non-separation between state and church (viz. religion) understood from the Indonesia constitution (Undang-Undang Dasar 1945) ${ }^{6}$ resulted in the state accommodation of religious institutions existing in society, and here religious education is undoubtedly one of the

${ }^{5}$ On the problem of managing Islamic educational institutions vis-a-vis secular institutions with the result of preserving the idea of dual system of education in Indonesia, see Donald J. Porter, Managing Politics and Islam in Indonesia (London and New York: RoutledgeCurzon, 2002), pp. 51-61.

${ }^{6}$ See Article 29 (1) of the Constitution of the Republic of Indonesia 1945 Amended, as stating: "The State shall be based upon the belief in the One and Only God.” 
most necessary agencies to consider. ${ }^{7}$ This is in line with the belief that by way of educational institutions, religious teaching can be preserved and passed on to the next generation. The preservation of this institution in society is therefore understood as a prerequisite for preserving religious existence. ${ }^{8}$ It is even argued here that religious educational institutions are not the same as other institutions since the former are basically related to religious survival in society. The amalgamation of religious and nonreligious educational systems might then not be viewed as appropriate. This is at least the argument still maintained by some groups proposing the separation between the two educational institutions in the country, although they might not be sure how to really separate the two.

The separation of institutions however does not resolve the more complex problem of the subjects taught in each educational institution. The question here is whether separation in management means separation in the kinds of subjects taught therein, particularly, whether secular educational institutions can teach religious subjects and vice versa religious institutions teach common, non-religious subjects. Interestingly, the answer is affirmative, that each institution can in fact deliver any subject, unrelated or related to religion, although the quantity is what makes the two institutions different. It is understandable that religious studies done in a religious education system are usually more intensive than what is done in non-religious one, resulting in the quality of studies between the two institutions being different as each has a different focus. Therefore, it is common that institutions under the management of the Ministry of Education are widely associated with high achievements in non-religious / common subjects, while those under the Ministry of Religious Affairs are strong in religious studies.

Thus, the double roof system cannot be defined as an exact

7 The institution of education is certainly one of the most important religious agencies the state needs to manage and organize if the inseparability of state and religion emanated in the constitution should be reflected in the state's responsibility towards religious life in the country. In the case of Indonesia, see in general, Donald J. Porter, Managing Politics and Islam in Indonesia.

8 On the question of whether we should privatize the religious education see Roger Trigg, Religion in Public Life: Must Faith Be Privatized? (Oxford: Oxford University Press, 2007), esp. 171-189; in the case of Turkey, see, Berna Turam, Between Islam and the State (Stanford, California: Stanford University Press, 2007), esp. pp. 67-88. 
substantive separation between religious and non-religious teaching institutions in Indonesia. This supports the old assumption that such a policy is mainly a consequence of the entrenched political rift between secular and religious (i.e. Islamic) nationalists on the idea of governing the state. In matters related to education, double management is understood as the only possible solution where the two camps can each have their own educational institutions to support their mission. Since education is understood as more a matter of political assertion, educational institutions are therefore not viewed merely from their functional role in educating people but more from their political function representing the existence of certain groups having specific agendas related to state building. This is done irrespective of any inefficiency that might result from the method. Put differently, separation of the educational management is accepted as the best solution combining the two ideas of secular and religious education existing in the country, and this should be done through all levels, from kindergarten to higher education, according to which both ministries have their own way of managing the system.

In the higher education system, the idea of separation has resulted in the existence of two institutions, the secular/common public university and the religious public university, built throughout the country since just after independence. As said earlier, although each of the two universities has its own concern, it is not uncommon that some subjects are offered in both institutions. One example is that both universities offer legal studies to their students. Beyond the fact that each has their own focus in teaching the subjects of law --namely that secular universities usually have their concentration on secular law while religious universities on religious law--, the double system can sometimes create a conflict of interest between the two institutions. One case is related to alumni from the two different universities. The question is, for instance, whether the graduates of the religious law faculty have the same capability to practice law as that of secular law graduates. In Indonesia, this is in fact not a simple question since it is not merely a problem resulting from the vague division in subject matters taught in two different institutions but, as explained above, also a consequence of the historical partition between secular and religious groups.

It is important to note that the difference between the two groups 
has manifested itself in society where different understandings and ways of thinking about how to manage social institutions have resulted in mutual distrust. In legal education, there seems to be a belief in society that the faculty of Syariah managed by Islamic universities or institutes cannot be equal to the faculty of law managed by secular universities. This means that students of Syariah faculties are believed to not have the same quality as that of their counterparts from secular law faculties. ${ }^{9}$ This is felt in the realm of legal practice also where, in contrast to lawyers from secular faculties, graduates of Syariah faculty are usually viewed as not having the capability in practicing law required to become a good lawyer in society. ${ }^{10}$ Seen from this perspective, the political grouping between secular and religious (Muslim) nationalists which arose soon after independence has thus permeated not only the realm of general thought on how to formulate the governing system in this country but also in practical aspects on how to deal with the social apparatus existing in society. It is true that the assumption of legal incapability of Syariah lawyers may not be based on any real findings in the field but more the result of political distrust still existing in the circle of secular lawyers. Yet, it is surprising enough that such a presumption has been maintained since independence and is still a dominant view embraced by secular lawyers in the country, irrespective of some improvements in the study of law undertaken in Syariah faculties recently. ${ }^{11}$

It is therefore important to analyze this case from the reality of legal studies done in the faculty of Syariah. It might not be an exaggeration to state that one of the main problems faced in the study of law in this faculty is the fact of its limited approach to study law from its practical dimensions. Many have argued that law and legal phenomenon in religious faculties are usually studied using the old perspective of law as a sacred institution where law is separable from the society at large, with the impact being that the process of law-making is seen as something occurring beyond the history of human beings. This is at least the argument put forward by many secular lawyers in the country, based on the fact that the curriculum in Syariah faculties puts more emphasis on the study of the

9 Interview with the Dean of the Faculty of Syariah and Law State Islamic University Sunan Kalijaga Yogyakarta, Yudian Wahyudi, November 15, 2010.

${ }^{10}$ Interview with Shari'áh lawyer, Taufik Ch., November 28, 2009.

11 Interview with a common lawyer, Nur Kholis, November 10, 2009. 
old figh (Islamic jurisprudence) aspects taken much from the old Arabic "yellow" book (Kitab Kuning). Many belief that studying Syariah from those old nomenclatures is indeed valuable but the problem is that such an emphasis will lead to Syariah studies being separated from the real and current problems faced by modern Muslim society. Furthermore, the old perspective of such Syariah studies will also have the effect of separating religious law from the legal phenomenon existing in the society at large. Syariah is taken as something confined from any other legal traditions in the lives of the people, having direct or indirect consequences to the growth of Syariah itself.

The direct consequence of such a perspective is the small portion of procedural law studies in the curriculum of Syariah faculties in the country. This seems to be the result of the common pattern in which the study of Syariah is done with more focus put on its theoretical, rather than practical, dimensions. Since most of the old books used in Syariah studies do not contain much material on aspects of procedural law, curriculum created in the Syariah faculty cannot but reflect such negligence. Compared to the curriculum in the secular law faculty, which usually offers significant time studying the practical aspects of law, curriculum in the Syariah faculty only contains about $3.5 \%$ on subjects related to the law of procedure or legal practice in general. ${ }^{12}$ Thus, beyond the fact of their common pattern in using the old perspective of law as merely past phenomenon, many believe that legal studies undertaken in the Syariah faculties has also been trapped, detaching the institution of Syariah from its practical need in society. This is absurd considering the inseparability of Islamic legal teachings from the society where the institution of law was born and matured, inseparable from the history of society itself.

It is thus not surprising that the alumni of Syariah faculties are seen as not sufficiently prepared to practice law when they graduate and decide to become an advocate. Mostly of the problem seems to relate

${ }^{12}$ From about 144 credits, there were only about 5 credits dealing with legal practice. As a comparative view, see the curriculum of the the Syariah faculties in five major state Islamic universities or institutes in Indonesia, namely in Aceh, Padang, Jakarta, Yogyakarta and Makassar. See also the current analysis of the curriculum of Syariah studies in Indonesian Islamic institutes and universities in M.B. Hooker, Indonesian Syariah: Defining a National School of Islamic Law (Singapore: ISEAS, 2008), pp. 85-128. 
to their insufficient background of knowledge concerning theoretical as well as practical aspects of working as a lawyer in society. Although debatable, the finding seems to support this presumption as many Syariah graduates are commonly reluctant to apply to become an advocate as they feel ill-equipped to plunge into the world of legal practice. Although an in-depth study is certainly needed to know the real picture concerning the quantity and performance of Syariah advocates in the country, this research appears to show the common picture where many Syariah graduates are not interested in applying to become an advocate as their job after graduation. Here, we find that besides the little attention paid to the study of legal practice in their curriculum, the graduates of this faculty are also sort of aloof from the world of the legal advocate. One question here is whether their inadequate interest in the work of a lawyer is due to their feeling of being unprepared or the result of the general orientation in the study of Syariah in the country which remains focused on the theoretical aspects of the law rather than its practice. Yet, whatever the answer, one reason is clear, that such a common attitude is in fact the result of the historical developments of the Syariah studies in the country, which certainly have different characteristics compared to legal studies done in the faculty of law, an outcome of their encounters with different socio-political conditions.

\section{Between Equality and Quality}

The above section has tried to explain that Syariah advocates in the country have basically had a double burden concerning their position in the milieu of common advocates in general. Socio-historical factors of the country seem to have trapped them in a difficult position: on one side, they are challenged with the long historical inequality of educational access between religious (Islamic) groups and secular groups, inherited basically from the Dutch colonial policy of pluralism; while on the other, they have to deal with the problem of being part of Muslim society with a legal culture where Islamic law is commonly viewed as irreconcilable with secular legal traditions. If the first is the problem related to the issue of equality between different groups in the country, which is basically the debate on how the country should manage its plurality as well as how to define the relationship between those different traditions, the second 
is however related to an internal problem faced by Muslim society in the country regarding how they understand Islamic law, which in turn influences their performance in general legal practice. Thus, we see here that the problems faced by Syariah advocates in the country cannot in fact be separated from the general problem of legal pluralism as it deals directly with how Islamic law and legal institutions can live in such a multicultural setting.

In terms of performance in legal practice, it remains a common belief that Syariah advocates cannot perform well due to their weaknesses in aspects of procedural law. ${ }^{13}$ This seems to be the main reason why many secular lawyers in the country cannot accept the idea of equality between Syariah and common advocates. It is interesting to note that while this argument has been made many times, in-depth studies have not been done yet to answer the question whether Syariah advocates are really weak in their practice of law. The argument itself seems however to have been taken for granted by most secular lawyers. Here, although one could accept the idea that training in legal procedure might be improved through courses designated specifically to improve the legal capability of these candidates, many still believe that Syariah graduates will never become as qualified as common law graduates.

Another argument persistently set forth in this case is to pinpoint the orientation of legal studies in the faculty of Syariah as a scapegoat. In this argument, as said earlier, the difficulty in attaining equality is due mainly to the orientation in the Syariah faculty, which stresses the study of law for the sake of mere knowledge without giving much attention to the aspects of legal practice in the courts. In other words, the curriculum of Syariah faculty has indeed very little in the practical aspects of law, and this certainly has an effect on the alumnae, particularly those intending to become legal advocates. Indeed, this might be true with regard to the Syariah curriculum of Islamic higher education in Indonesia which until quite recently neglected many aspects of judicial legal practice needed to implement the knowledge of law studied therein. ${ }^{14}$

13 See "Tragis, Hanya Tujuh Sarjana Syariah yang Lolos Calon Advokat," Hukum Online, 20 July 2007, accessed from_http://www.hukumonline.com/detail. asp?id=17192\&cl=Berita. Taken 12 January 2009.

${ }^{14}$ See the percentage of the Syariah curriculum in note 13. See also Hooker, Indonesian Syariah, pp. 85-128. 
However, in terms of curriculum, one may need to consider some improvements undertaken recently in Syariah faculties throughout the country. In conjunction with recent positive changes implemented in Islamic higher education, Syariah faculties in Islamic universities or institutes have also improved their quality, especially related to the study of Syariah and its relation to other legal traditions. There seem to be at least two factors influencing such a positive development. Firstly, there is a growing consciousness in civitas academica of the Syariah faculties in the country for the need to bring the study of Syariah closer to that of secular law. The orientation of Syariah studies is not confined anymore to the mere study of past legal traditions inherited from the works of past Islamic legal experts and jurists but to include also other legal traditions existing in modern society at large. As for the curriculum, this changed approach results in a more open minded attitude towards secular legal traditions. Many new subjects related to modern views of law and how they can be implemented in a multicultural setting have thus been recently adopted in the new curriculum of many Syariah faculties. ${ }^{15} \mathrm{We}$ see therefore new subjects such as legal drafting, modern legal theories, civil law system, comparative law theory, etc., appear in the curriculum to expand the study not only of the mere internal substantive aspects of religious law but also many more current legal perspectives usually associated with secular law. ${ }^{16}$

Secondly, in conjunction with this new approach, where Syariah is not anymore a secluded legal tradition, the study of religious law has also now taken a practical orientation in its approach. Some credits in the Syariah curriculum are now designed specifically to expand the study of law in its practical aspects. ${ }^{17}$ Some subjects, such as the law of procedure, legal advocacy, legal clinic, etc., are taught in the faculty to equip students for many aspects of legal practice they might use after

15 See the current improvements of the Syariah curriculum in some state Islamic universities, in UIN Jakarta, UIN Yogyakarta and others. See note 12 above.

${ }^{16}$ See those subject matters taught in the current Faculty of Syariah and Law, State Islamic University Sunan Kalijaga Yogyakarta in Fakultas Syariah dan Hukum, "Kurikulum Fakultas Syariah dan Hukum, Universitas Negeri Sunan Kalijaga Yogyakarta, tahun 2008-2012", document with the author.

17 Ibid. 
graduation. ${ }^{18}$ Put differently, the change in approach to studying Syariah has led them to avoid placing religious law as a legal tradition separated from other secular laws in the country, directly resulting in the addition of many aspects of legal practice to the curriculum. This is in line with the new perspective of Islamic law as not just law-in-book matters but law-in-practice as well.

The development as described above seems currently to be undertaken institutionally using a formal approach which transforms not only the substantive aspects of the curriculum but also the label of the faculty. Thus we see that a number of Syariah faculties in Indonesia have now modified their name to the "Faculty of Syariah and Law." 19 Adding the term "law" after "Syariah" is in fact not a trivial matter; it reflects a new shift whereby Syariah is not seen as an entity separate from other (secular) laws in general. The study of Syariah should therefore incorporate other legal traditions, both secular and profane. This is indeed a new development marking a new approach in this study done by the institutions of higher education under the Ministry of Religious Affairs. Although some Muslim experts may not fully accept the idea, the changed name of the faculty is important as it symbolizes a new understanding of Syariah and how Muslim society in the country should treat it. In practical matters, the new name is indeed an important response to the reservation of many secular lawyers and jurists in the country and to the need of the faculty to produce law graduates with standard knowledge and capability of legal practice.

${ }^{18}$ See for instance the development of curriculum in the Faculty of Syariah, State Islamic University Sunan Kalijaga Yogyakarta, in Pokja Akademik UIN Sunan Kalijaga Yogyakarta, Kompetensi Program Studi Universitas Islam Negeri (UIN) Sunan Kalijaga Yogyakarta (Yogyakarta: Pokja Akademik UIN SUKA, 2006), p. 65-100.

19 Although not many Syariah faculties have yet formally used the new name of Syariah and Law due to an uneasy bureaucratic process dealing with the government's permission, more and more Syariah faculties seem to follow the same pattern, the most important of which by offering more subjects of secular law to their students. A number of Syariah faculties having altered their name are for instance: Faculty of Syariah and Law, State Islamic University Syarif Hidayatullah Jakarta; Faculty of Syariah and Law, State Islamic University Sunan Gunung Jati Bandung; Faculty of Syariah and Law, State Islamic University Riau. While Faculty of Syariah of State Islamic University Sunan Kalijaga Yogyakarta has also recently followed the same step adopting the new name of Faculty of Syariah and Law. 
Beyond the pros and cons, many indeed hope that the new name will bring the old Syariah faculty towards a new orientation of legal study where secular laws and legal institutions as well as their practice are studied intensely alongside Islamic legal studies. If so, it is not an exaggeration to say that the new name itself is without a doubt very phenomenal in the history of Syariah studies in the country as it reflects a positive development, not only expanding the curriculum in which the study of the religious (Islamic) law can be enriched with the study of secular laws but also the structure of the faculty itself. Seen from this premise, the idea of changing the faculty label is just one of many ways to assure public audiences, especially those of secular lawyers and jurists, that the Syariah educational institution is in fact at an equal level with that of law faculty since there are no substantive differences between the two. By so doing, there is an expectation that this institutional reformation should in turn result in the recognition of Syariah graduates, particularly those deciding to become lawyers practicing law in society, since in terms of their educational institution, the Syariah graduates and law graduates have basically no intrinsic differences.

The struggle to achieve such equality by way of improving Islamic legal educational institutions seems however not to have succeeded in touching the practical aspects of law. In the realm of the legal advocate, there is a persistent hesitation among secular lawyers and jurists regarding the capability of Syariah graduates to become a lawyer. This was clear in the debate both inside and outside the parliament on the recognition of Syariah graduates when the draft of the law of advocate came to the legislative assembly in early 2000s. In this case, the old question came to the surface again at the time when the parliament members discussed the draft of the bill, especially related to Article 2 (1). The central question was whether Syariah graduates could be recognized as having the same status as law graduates. Or, specifically, whether the Law could accept the idea of the Syariah faculty having the same standing as that of common law, so that their graduates could be accepted as lawyers. In response to the debate, for instance, one famous lawyer in the country, Adnan Buyung Nasution, at that time explained his hesitation about the capability of 
Syariah graduates in the practice of law. ${ }^{20} \mathrm{He}$ was thus representing the voice of many secular lawyers who generally lacked confidence that the Syariah faculties could produce qualified lawyers.

This was in fact the group that believed in the idea that legal studies in the faculty of law would not be able to produce a good lawyer if they are not supported by comprehensive studies of legal practice, focusing on the fact that Syariah students mostly spend their time studying "Islamic law in-book" only and not "(Islamic) law in-practice". And since the legal system working in the country is basically a secular system, Islamic law is basically unfit for the practice of secular law. These are the basic arguments set forth to explain that Syariah graduates are not qualified enough to become a lawyer. In turn, they were of the opinion that since Syariah graduates cannot achieve the basic standard of an advocate, the bill should therefore explicitly define the legal background required of an advocate, according to which Syariah background is excluded.

Interestingly, the arguments put forward by the above group were not left unchallenged. As one may expect, the hardest rebuttal was indeed expressed by Syariah lawyers and jurists in the country who viewed the first group as candidly representing the views of secularists who always misunderstood Syariah and thus tended to underestimate Syariah students. In contrast to the first group, this group defended Syariah graduates for achieving equality vis a vis secular law graduates. ${ }^{21}$ It is the right of all law students, including those of the Syariah faculties, to become a lawyer. The argument for limiting the position only to secular law graduates, they argued, would thus be absurd as it blatantly denigrated students of Syariah, as if they could never come to the same level as their counterparts. They understood that such a vilification would only result in a much deeper gap between the two different law graduates, a gap basically reflecting the legacy of the old division between secularist and Muslim groups since early independence. Although realizing some weaknesses still existed in many Syariah faculties, this group challenged

${ }^{20}$ See some articles for instance "Prof. Mardjono: Asal Lulus Ujian, Sarjana Syariah Bisa Jadi Advokat," Hukum Online, 21 October 2002, http:/ /www.hukumonline. com/detail.asp?id=6696\&cl=Berita, accessed $27^{\text {th }}$ January 2009; "UU Advokat, Cermin Langkah Mundur," Kompas Online, 10 April 2003, http:/ /www2.kompas.com/kompascetak/0304/10/nasional/249211.htm, accessed 27 ${ }^{\text {th }}$ January 2009.

${ }^{21}$ Interview with Taufik Ch., November 28, 2009. 
the sophistic arguments promoted by the first group that the law of advocate should limit the profession of advocate to only those alumnae of secular law faculties. In their view, since Islamic law is an established legal tradition accepted in the multicultural society of Indonesia, the limitation would only negatively impact the national legal system in general. The definition drafted in the Art. 2 (1) of the bill should therefore include all law graduates, with no exclusion of any kind of law faculty. It is only by making the law inclusive in its character that rapprochement between secular and Syariah lawyers is possible.

It is in this context that the struggle of many Syariah lawyers to achieve equality with other lawyers in the country is indispensable. Here, the promulgation of the Law of Advocate is understood as the culmination of their efforts to achieve their goal, as it could be a solution to the problem that has so far haunted their existence. This is why they were so determined to make the law receptive towards Syariah advocates as it could mark the acceptance of Islamic law in the country's legal system. In so doing, the Law will certainly function as the main door for Islamic legal teachings being implemented in society, through a proper lawyer well-versed in the substantive aspects of religious law. In other words, the Law of Advocate -which is inclusive in its character-- will serve as an assurance for the implementation of Islamic legal teachings in the hands of experts, ie. Syariah advocates. ${ }^{22}$ Seen from this perspective, the birth of the Association of Indonesian Syariah Advocate (Asosiasi Pengacara Syariah Indonesia, APSI) can be understood within the context of the struggle of Syariah advocates at the time to gain their goals, equality with common lawyers in the country and quality as a qualified lawyer in the milieu of the country's system of law.

\section{The Ideas and Ideals of APSI}

As a formal association of advocates, APSI was established in February 8, 2003, although the activities of its members started years before in conjunction with the common struggle of Syariah advocates to gain equal recognition --as described above. Yet, the establishment of the association in early 2003 was indeed a momentous event for the history of Syariah advocates in the country as it symbolized their struggle, which

${ }^{22}$ Interview with a director of APSI, Taufik Ch., November 28, 2009. 
occurred not only in informal forums but now also through a formal legal institution, similar to the association of common advocates. Without a doubt, the year 2003 provided important momentum for Syariah advocates as many events took place marking a positive contribution to the history of Syariah advocates in Indonesia, in the midst of the changing situation of the country's political landscape.

One of the most important events during the early development of the association was undoubtedly the promulgation of the Law of Advocate itself, formally passed by the legislative assembly on $6^{\text {th }}$ March 2003, about a month after the establishment of the association. As the basic regulation of the legal advocate in the country, the Law No. 18 of $2003^{23}$ is indeed the epitome of the long and tiring struggle of Syariah advocates to gain formal recognition by the state. This development, of course, cannot be understood without considering the mission of APSI since its initial establishment. As explained in APSI's statement of profile, ${ }^{24}$ the successful promulgation of the Law marks the early success of APSI (and of course Syariah advocates in general) since the Law formally recognized the role of Syariah advocates in the practice of law in the country's legal system. Article 2 (1) of the Law mentions clearly that persons who can be accepted as legal advocate are "those having higher legal education background." 25 This Article does not define whatsoever from what kind of law faculty graduates must come in order to be legally accepted as a lawyer. Thus, such a common term means that the faculty of Syariah may not be excluded as the latter is also part of the law faculties existing in the country, regardless of the fact that the faculty also has common legal studies as its subject matter.

Candidly, the explanation of the Article supports this common understanding. It states that "what it means by having higher legal education background is those graduated from the faculty of law, Syariah, military law

23 The Law No. 18 of 2003 on Advocate, State Gazzette No. 4288. See at http:/ / www.legalitas.org/database/puu/2003/uu18-2003.pdf

${ }^{24}$ Dewan Pimpinan Pusat APSI, "Profil Asosiasi Pengacara Syariah Indonesia," p. 1. Document with the author.

25 See the wording of Article 2 (1) of the Law No. 18 of 2003: "Yang dapat diangkat sebagai advokat adalah sarjana yang berlatar belakang pendidikan tinggi bukum dan setelah mengikuti pendidikan khusus profesi advokat yang dilaksanakan oleh organisasi advokat". (Italics mine). 
academy, and police academy" (Italic mine).$^{26}$ Many believe that the mention of Syariah faculty in this explanation represents deliberate support from the state for the existence of Syariah advocates. And this undoubtedly is incontrovertible support for the long struggle of many Syariah lawyers and jurists in their struggle to achieve equal rights in legal practice. For APSI, this is an inalienable part of the basic rights of graduates from the Syariah faculty if they are willing to work as legal advocate. In turn, this is also an indication that the existence of APSI in the milieu of other advocate associations has also been recognized.

In terms of the state recognition of the existence of APSI, the Law clearly mentions APSI as one among eight advocate associations legally included in the organization of Indonesian lawyers, thus having the right to organize Syariah advocates in the country. ${ }^{27}$ This recognition has become a great foundation for APSI proponents to continue their

${ }^{26}$ See the wording of the explanation of Article 2 (1) of the Law: "Yang dimaksud dengan 'berlatar belakang pendidikan tinggi bukum' adalah lulusan fakultas bukum, syariah, perguruan tinggi bukum militer, perguruan tinggi ilmu kepolisian". (Italics mine).

27 Article 32 (2) of the Law of Advocates mentions the eight advocate associations which legally include in the organization of advocate: Ikatan Advokat Indonesia (IKADIN), Asosiasi Advokat Indonesia (AAI), Ikatan Penasehat Hukum Indonesia (IPHI), Himpunan Advokat dan Pengacara Indonesia (HAPI), Serikat Pengacara Indonesia (SPI), Asosiasi Konsultan Hukum Indonesia (AKHI), Himpunan Konsultan Hukum Pasar Modal (HKHPM), and Asosiasi Pengacara Syari'ah Indonesia (APSI). It needs an explanation here that when the Law of Advocates was drafted in early 2000 , there were already 7 advocate associations existing in the society and effectively organized many lawyers and advocates in practicing the law before the courts. Those associations were: The Indonesian Advocates' Association (Ikatan Advokat Indonesia, KADIN), The Association of Indonesian Advocates (Asosiasi Advokat Indonesia, AAI), The Indonesian Legal Advisors Association (Ikatan Penasehat Hukum Indonesia-IPHI), The Indonesian Advocates and Lawyers' Association (Himpunan Advokat dan Pengacara Indonesia, HAPI), The Indonesian Lawyers' Union (Serikat Pengacara Indonesia, SPI), The Association of Indonesian Legal Consultants (Asosiasi Konsultan Hukum Indonesia, AKHI), The Indonesian Capital Markets Consultants' Association (Himpunan Konsultan Hukum Pasar Modal, HKHPM). Interestingly, when the Law was promulgated in 2003, the number of the association was increased to eight as the new association was established to specifically deal with Syariah advocates, namely, the Association of Syariah Advocates in Indonesia (Asosiasi Pengacara Syariah Indonesia, APSI). That is why the Law Art. 32 captivatingly mentions those all eight associations, including APSI, to be emanated as the official associations to implement the principles of the Law before the sole bar association is successfully established, in par with the Law. 
struggle in building the self confidence of many Syariah advocates in handling cases related to Syariah. This is true as seen from the legal support it receives, as the state has fully sustained the association in undertaking its mission and vision, the most important of which is to help Syariah advocates in the country advance the quality of their work in legal practice. ${ }^{28}$ The mention of the APSI association in the Law of Advocate will only strengthen its position as a legal association having the same standing as other advocate associations. This will in turn give assurance that the state has formally recognized Syariah as one legal tradition included in the system of law of the country. The practice of religious law will therefore be done in one system, inseparable from that of other laws. If so, the state has just proven itself to have given its formal recognition of Syariah in society, not only in aspects of substantive law but also those related to legal practice, according to which a special lawyer is willy-nilly designated to uphold the practice of religious law in formal state legal institutions. This seems to be one of the main goals of the establishment of APSI, in which recognition of APSI means recognition of Syariah advocates and vice versa the recognition of Syariah advocates makes possible the recognition of their association.

The recognition of APSI as stated in the Law Art. 32 (2) has indeed benefited the association, strengthening its mission. Since the promulgation of the Law, APSI has been involved in the process of establishing a single formal association of Indonesian advocate. From the beginning, APSI has had a role, together with the other seven advocate associations, in the Working Committee of Indonesian Advocates (Komite Kerja Advokat Indonesia, KKAI) to create a unified advocate organization. As a result, in December 21, 2004, APSI and other advocate associations signed the declaration of the establishment of the Confederation of Indonesian Advocate (Perhimpunan Advokat Indonesia, PERADI) functioning as one official advocate organization in the country. In this organization, the chair and secretary of APSI are included in the board committee of the Confederation, thus officially included as the founders of the PERADI. ${ }^{29}$ This involvement is certainly

${ }^{28}$ See Article 1 of the "Anggaran Rumah Tangga APSI" in DPP APSI, "ADART APSI", p. 11. Document with the author.

29 Dewan Pimpinan Pusat APSI, "Profil Asosiasi Pengacara Syariah Indonesia," p. $1-2$. 
beneficial in strengthening the political support needed to develop the young APSI institutionally, which later will help alleviate the position of Syariah advocates in the environment of common advocates in the country.

Since its establishment in 2003, APSI now has no less than 16 provincial branch offices throughout Indonesia, besides a number of branches in some regencies, mainly in Java. ${ }^{30}$ This shows that in five years, APSI has successfully developed its organization, representing the real enthusiasm of society for the existence of a Syariah advocates association. It seems clear here that due to the political support already given by the state, the association has already received many positive responses from common lawyers and jurists in the country as well as from Muslim society at large. From the perspective of many lawyers, the fact that APSI is mentioned in the Law of Advocate as one of the eight associations officially given the right to organize advocates is a strong legal basis to indisputably accept the existence of the association of Syariah advocates. While from the perspective of Muslim society, their acceptance is in itself necessary for implementing Syariah, especially when faced with cases related to state legal institutions. Here, the need of Syariah advocates involves basically two aspects correlated with each other, firstly, that Syariah advocates are best qualified for dealing with Syariah-related cases since they are deemed as the ones well-versed in substantive Islamic law; and secondly, due to the belief that they are the most suitable advocates to give legal services to Muslim parties, especially as concerns the law of procedure. All in all, it is safe to assume here that seen from the perspective of legal institutions, APSI has received a positive response from the public, although efforts to improve its capacity building continue as part the process of its ongoing development.

It is unexpected however that such significant institutional support does not seem to be followed by more attention from Syariah graduates in the country. It is here that we find an interesting phenomenon where the political support given from above, i.e., state institutions, to the association of Syariah advocates does not run parallel with the interest from below, the Syariah graduates. The data shows that most of APSI's

${ }^{30}$ Interview with M. Nur Khoirin, the secretary general of APSI, on January 27, 2009. 
members are alumni of the faculty of law and not the faculty of Syariah. ${ }^{31}$ Thus, we find that about $80 \%$ of them have graduated from secular law faculty with the title of Sarjana Hukum (BA in Law), while those with the title of Sarjana Hukum Islam (BA in Islamic Law) only represent at most 20\%. ${ }^{32}$ The data given by the Director of APSI National shows that there are now about 500 Syariah advocates spread all over the country who are official members of APSI. ${ }^{33}$ Interestingly, of those 500 advocates, males dominate, with the ratio of more than $90 \%$ male and $10 \%$ female. We can see therefore that, at most, there are only about 100 APSI advocates who have been equipped with the proper background in Syariah, while the remaining 400 are associated with a non-Islamic law background. Although the number is not exact and practicing advocates are in fact mostly centered in the big cities in the West and Central part of Indonesia, the data itself can optimistically reflect the dramatic increase in the number of Syariah advocates practicing in the last five years. ${ }^{34}$ This is of course beyond those Syariah advocates who might have associated themselves with other bar organizations, if we want to consider the total number of Syariah advocates in the country at large. This, indeed, could be one of the biggest challenges for APSI, to develop its institutional mission since the fast growth of its organization has not succeeded in attracting significant support from the Syariah graduates.

There are some factors that seem to have led to such a relatively low number of Syariah advocates becoming members. Firstly, there is no requirement from the Law of Advocates that Syariah advocates should join the membership of APSI. According to the explicit wording of the Law, an advocate may join any of the eight bar organizations mentioned in Article 32, so membership in APSI for Syariah advocates is not obligatory. Secondly, the extension of APSI offices has not reached the vast number of places throughout the country. This may result in only a few Syariah advocates being able to access APSI's programs and activities. Yet, beyond

31 Dewan Pimpinan Pusat APSI, "Profil Asosiasi Pengacara Syariah Indonesia," p. 3. Interview with the Director of APSI, Taufik Ch., on November 28, 2009.

32 Interview with Director of APSI Yogyakarta branch, Budi Ruhiatudin, on December 11, 2009. According to him, there are only about $15-20 \%$ of the whole APSI members in the country who had a background in Syariah education.

33 Interview with Taufik Ch., on November 28, 2009.

34 Interview with Taufik Ch., on November 28, 2009. 
this situation, one thing seems to be assured, that slowly but surely APSI's membership has developed significantly in a relatively short span of time in line with the improvement of Muslim society in understanding the organization..$^{35}$ It might not be an exaggeration to suggest that the domination of secular law graduates involved in APSI organization may be problematic for the association itself, although this does not theoretically transgress the constitution of the APSI. Yet, according to its secretary general, Nur Khoirin, the large number of secular law graduates in the association just represents the fact of the scarcity of Syariah graduates interested in applying to become an advocate. ${ }^{36} \mathrm{He}$ seems thus to say that the small number of Syariah graduates in the association is only part of a larger phenomenon of Syariah faculties where the profession of legal advocate does not commonly attract students. It is true, this may create such a situation where the proponents of the association of Syariah advocates are dominated by common advocates, but we should not forget that the small number of Syariah advocates in the association is inseparable from the general situation of Syariah faculties in the country, where legal advocate is not oriented yet as the main choice of profession.

This should become the focus of APSI programs now. The scarce involvement of Syariah graduates in the association can only be solved through developing networks within Syariah faculties, since the latter is basically the main place to produce Syariah lawyers and jurists. ${ }^{37}$ In other words, the APSI's program to further develop its capacity building throughout the country cannot be effective without involving the best partner to work with. And Syariah faculties are certainly the best choice here. Historically, the association was established with a similar basic mission as that developed in the faculty of Syariah, namely, to facilitate the implementation of Syariah in the country's legal system. This will not be possible without a close relationship between the two institutions, as from the Syariah faculty we set our hope in having qualified Syariah lawyers and jurists, while the association can facilitate Syariah graduates in becoming qualified lawyers, well-versed with legal practice. In line

35 Interview with Taufik Ch., on November 28, 2009.

36 Interview with Nur Khoirin on January 6, 2010.

37 Interview with director of APSI, Taufik Ch., on November 28, 2009. 
with this idea is that since its early establishment, APSI has tried to expand its partnership with many Syariah faculties in the country. ${ }^{38}$ In cooperation with those faculties, APSI usually organizes activities related to legal practice. The most common activity is organizing a workshop on legal advocacy done every year under the auspices of the Ministry of Religious Affairs. Until quite recently, there have been no less than 10 Syariah faculties or departments that have held workshops for students wanting to understand more about being a lawyer and legal practice in general. ${ }^{39}$ Although the number of faculties involved in the project is still limited, it is believed to have given a good impression to other Syariah faculties and departments, not only in relation to understanding APSI's mission but also generally to the service of law.

Besides facilitating programs for fresh Syariah graduates to help them get acquainted with the world of the legal advocate, another important program done periodically by APSI is organizing a special course of advocate for those graduates willing to step into the profession (Pendidikan Khusus Profesi Advokat, PKPA). This is a kind of short course undertaken as preparation before the participants take the bar exam. According to Law No. 18 of 2003, PERADI is the official organization for offering the course to those interested in becoming an advocate. And as one of the members of PERADI, APSI is the official association having the right to organize the course particularly for the Syariah advocate. That is why PKPA is one of the main programs offered by APSI regularly. The most effective way to hold this program is through cooperation with Syariah faculties from which participants can be recruited. APSI has so far been able to work with 6 major Syariah faculties in Java and Sumatra for organizing the PKPA course, and the number will likely increase in the future in conjunction with the number of Syariah graduates interested in working as an advocate. ${ }^{40}$ This seems to be the main role played by APSI, preparing qualified Syariah advocates, and so an intensive course is therefore needed to facilitate them succeeding in admittance.

${ }^{38}$ Dewan Pimpinan Pusat APSI, "Profil Asosiasi Pengacara Syariah Indonesia," p. 5.

39 Ibid., p. 6.

40 Ibid., p. 5-6. Interview with the secretary general of APSI on January 6, 2009. 


\section{E. Syariah Advocates and Legal Pluralism}

The question whether Syariah advocates in Indonesia can finally achieve their ideal of equity and equality is in fact inseparable from the general problem of legal pluralism in the country. The case of Syariah advocates is here seen as part of the phenomenon of Islamic law existing in a multicultural country with varied legal traditions which are theoretically accepted as raw material for building a secular national legal system. It is thus understandably important to see the case from the perspective of legal pluralism.

The above paragraphs have clearly shown also how the struggle of Syariah advocates for equity in the service of law has for the most part been successful, thanks to the role played by the APSI association. According to the rights given by the Law of Advocate, APSI has been able to facilitate Syariah advocates in improving their quality in order to achieve equal status with common advocates. This is the most important role played by APSI since the struggle for such equality may not be realized without an official institution to work with. The achievement of APSI in this case may seem simple but essential for Syariah advocates in the country owing to the fact that their efforts may not work if unsupported by such an official association. It is thus surprising that the attention shown by most Syariah faculties towards APSI programs seems not adequate to support the struggle. As said earlier, this low involvement on the part of Syariah faculties may be the result of the common pattern of most Syariah students remaining aloof from the aspects of legal practice in the country. Thus, as legal service is commonly neglected in the study of Syariah, an institution such as APSI will be viewed as less relevant for the faculty.

The need for an advocate to give legal assistance when dealing with legal cases is in fact an unavoidable necessity in a modern society being created in a developing country such as Indonesia. Using Galanter's analysis, this is what he calls the consequence of modern legalism. ${ }^{41} \mathrm{In}$ a detailed elucidation, he has pinpointed eleven elements of modern law to be built in a modern nation state, one of which stresses the need

${ }^{41}$ Marc Galanter, "The Modernization of Law," ed. by Myron Weiner, Modernization: The Dynamics of Growth (Washington: United States Information Service, 1967) 167 , p. $168-170$. 
of professionals to uphold such a legal system. This is because modern law is basically uniform in its application, meaning that the rules created in the process of modern lawmaking are not personal but "territorial," therefore, "the same rules are applicable to members of all religions, tribes, classes, castes, and localities and to both sexes." 42 This has the consequence of full-time staff being chosen on the basis of mundane and demonstrable qualifications, namely, their professionalism in legal techniques, and not on special gifts or talents accessible to only particular persons. Lawyers are needed more now than ever as the modern legal system becomes more technical and complex in its application. The lawyer is here understood as a trained agent who can act as mediator between the courts and the layperson.

In a multicultural country such as Indonesia, the lofty idea of legal modernism can in practice collide with the fact of legal pluralism existing in society. As concerns Syariah advocates in Indonesia, for example, the need of modern legal practice does not always run parallel with the old tradition of Islamic law existing in classical (non-state) legal institutions. Thus we find that although many aspects of substantive Islamic law have been adopted as raw material of National Law, practicing the law in the system of the state is not as easy as its substantive adoption. This seems to be the case with the equality problems faced by Syariah advocates. Their difficulty to adjust to the modern practice of law may have been the result of their deep embrace of a culture different to the new modern legalism of the state. In other words, there might be a clash of cultures here, between the old tradition of legal practice in Muslim societies and the new tradition imposed by the state. If so, the problem related to Syariah advocates may be a common problem usually arising in the process of legal modernization. In the specific case of the law of procedure, for instance, we find that Syariah faculties in the country have adopted very slowly the idea of modern procedural law in their teaching curriculum, since Islamic law does not basically teach in detail, using Hart's term, law in its secondary rule. ${ }^{43}$ Therefore, almost all parts of the faculty's syllabus are filled in great detail with the old substantive teachings of Islamic law

${ }^{42}$ Galanter, "The Modernization of Law," p. 168.

${ }^{43}$ H.L.A. Hart, The Concept of Law (Oxford: Clarendon Press, 1961), p. 78 onward. 
- embodied in the old books of fiqh — - resulting in an uneasy incorporation of the subjects of modern law of procedure. Many alumnae of Syariah faculties find themselves therefore in an awkward situation when faced with the need to fulfill the requirements of legal advocate.

Therefore, the real situation of the Syariah faculty in most Islamic higher education institutions in Indonesia may cause many proponents of the Syariah advocate association to not confine themselves in the small box of the Syariah circle. That seems to be the main reason why, since its creation, the association has not limited its membership to only graduates of Syariah faculty. This is reinforced in the constitution of the organization which states that anyone having legal education background (both from Syariah faculty and law faculty) can become a member of the association, as long as they have a commitment to support the advancement of the organization in society. ${ }^{44}$ We find therefore that the label of Syariah advocate in the association (APSI) is not meant to limit the association to only Syariah advocates. ${ }^{45}$ The two kinds of graduates are even seen as complementary to each other, as each has its own strengths and weaknesses needed to improve the legal practice of Syariah in the country. APSI seems in this case to prefer being an open institution in which all people who have the same interest in Islamic law can join and work together. ${ }^{46}$ This is certainly undertaken to help orient Islamic legal studies as a study inseparable from other legal studies in general, so that Syariah graduates are not separated from secular law graduates, particularly when they want to step into the realm of legal advocacy.

From the perspective of legal pluralism, the case of the Syariah advocates association above reflects very aptly the efforts of some Muslim lawyers in the country to answer the old problem of the place of Islamic law in a multicultural society. They seem to believe that the

${ }^{44}$ The Constitution of APSI Article 4 states that there are 4 kinds of APSI's members: Regular Member, Unordinary Member, Privileged Member and Special Member. See the explanation in Article 4 of the "Anggaran Rumah Tangga APSI" in DPP APSI, “AD-ART APSI”, p. 12.

${ }^{45}$ It is interesting to note also that a few APSI members are non-Muslim advocates, interested to deepen their practice of Islamic law. Interview with the Director of APSI, Taufik Ch., on November 28, 2009; and with Director of APSI Yogyakarta branch, Budi Ruhiatudin, on December 11, 2009.

46 See Article 2 of the "Anggaran Rumah Tangga APSI" in DPP APSI, "ADAR'T APSI", p. 11. 
best response is to not approach religious law as a compartmentalized legal tradition existing separately from others, such as civil or adat legal traditions. If this is the case, then there seems to be a different pattern here in approaching the problem. My previous studies have shown the current tendency to place substantive Islamic law in a position as a separate law having no relationship to other traditions. ${ }^{47}$ Thus, among the three methods in legal encounters between different legal traditions, the state tends to prefer taking legal compartmentalization as a choice, rather than legal acculturation or legal assimilation. ${ }^{48}$ The promulgation of a number of substantive Islamic laws into some new laws (UndangUndang) recently has just proven the tendency of such a method of compartmentalization. It is through this method that the "positivization" of Islamic law is undertaken by way of creating separate statutes whose contents are independent from any influence of other legal traditions. This seems also to support the established independent Islamic courts that were created some decades ago, separate from other common courts.

In matters of legal procedure, however, the tendency seems to show a different approach. Although the development of the institution of the Islamic court may have been done through such a compartmentalized approach, the system of legal procedure follows a different path. Here, there is only one law, to which all people, having different legal backgrounds, should conform. Thus, in the practice of law, there is no difference whether a case is filed in the Islamic courts or in the common courts, as the procedure is uniform and both courts are part of one system, namely the state court. This seems to follow the kind of thinking that guides APSI, an open organization, whose membership is not only limited to Syariah lawyers but basically for all lawyers in the country. In other words, although the label and the concern of the association may specifically deal with the service of Islamic law, all lawyers in the country can be involved in such a service. This might be the best solution in

47 See Ratno Lukito, Hukum Sakral dan Hukum Sekuler: Studi tentang Konflik dan Resolusi dalam Sistem Hukum Indonesia (Jakarta: Alvabet, 2008) esp. "Kesimpulan”, pp. 500-518; Ratno Lukito, Interpersonal Law in Modern Indonesia (Yogyakarta: CLSC, 2007); and Ratno Lukito, Legal Pluralism in Indonesia: Bridging the Unbridgeable (New York and London: Routledge, forthcoming).

${ }^{48}$ In detail about the three methods see Ratno Lukito, Legal Pluralism in Indonesia: Bridging the Unbridgeable, esp. "Theoretical Implications." 
facing the reality of legal pluralism in the country, meaning a plurality in legal actors working to give legal service to the society. Here comes to the surface the view that the rigid division between Syariah and common lawyers in the country will only complicate the already complex problem of the encounter between different legal traditions, since in the practice of law, cooperation between different lawyers is commonly needed.

\section{F. Conclusion}

Living in a situation of complex legal pluralism, Syariah advocates in Indonesia have faced some problems as a result of their encounters with common advocates. They have to deal with at least two problems, namely, inequality compared to their counterparts (the common advocates) and the problem of the low quality in legal service, with the first problem basically being the result of the second. This paper has tried to show that in their struggle to arrive at their goal of equality, Syariah advocates have made some efforts to overcome these problems, one of which has been through the establishment of the association of Syariah advocates (APSI). As the association specifically created to facilitate Syariah advocates in the country, APSI has successfully attracted attention from the state and public in general, although the interest shown by Syariah faculties remains relatively low.

It is interesting to note that APSI seems to prefer approaching the problem of Islamic legal service from an inclusive perspective. APSI is designed to be an open institution where not only Syariah graduates can join, but common law graduates as well. This seems to be planned as a way to bridge the gap between the two camps of Islamic and secular law faculties, so that their graduates can work together in the same place. From the perspective of legal pluralism, this approach is in line with the idea of an "integralistic" national law where the uniform law created in the pluralistic state of Indonesia can basically accommodate all different values of legal traditions in the society. As the Law No. 18 of 2003 on the advocate confirms the equal position of Syariah advocates with other advocates practicing law in the country, the APSI's inclusiveness is the most appropriate way to ensure such equality. In this case, the compartmentalization method, as used by the state in the realm of substantive Islamic law, appears not to work with the law of procedure, 
Ratno Lukito

according to which all lawyers in the country are in the same position before the law, irrespective of their background. 
Syariah Advocates' Struggle for Equality in Indonesian Legal Pluralism

\section{BIBLIOGRAPHY}

Abdullah, Ra'ouf M., "Can a Person be a Believer and a Secular Government Lawyer Too?", Journal of Islamic Law and Culture 4 (1999): 11.

Abel, Richard L., "Lawyers and the Power of Change", Law and Policy 7 (1985): 5.

Chaudhry, Ijaz Manzoor, "The Shura Law Center, Inc.: A Communitybased Islamic Legal Service," Journal of Islamic Law and Culture 1 (1996): 237.

----, "Choosing Law as a Profession: the Role of Muslim Attorneys," Journal of Islamic Law and Culture 4 (1999): 21.

Dewan Pimpinan Pusat APSI, Profil Asosiasi Pengacara Syariah Indonesia. ----, AD-ART APSI.

Galanter, Marc, "The Modernization of Law," ed. by Myron Weiner, Modernization: The Dynamics of Growth, Washington: United States Information Service, 1967.

Haq, Irshad Abdal, "The Role of the Muslim Lawyer in Establishing Islamic Community Life," Journal of Islamic Law and Culture 3 (1998): 105.

---- \& Qadir Abdal Haq, "Community-Based Arbitration as a Vehicle for Implementing Islamic Law in the United States," Journal of Islamic Law and Culture 61 (1996): 61.

Hart, H.L.A. The Concept of Law, Oxford: Clarendon Press, 1961.

Hooker, M.B., Indonesian Syariab: Defining a National School of Islamic Law, Singapore: ISEAS, 2008.

Law No. 18 of 2003 on Advocate, State Gazzette No. 4288. Accessed at http://www.legalitas.org/database/puu/2003/uu18-2003.pdf.

Lobel, Orly, "The Renew Deal”, Minnesota Law Review 89 (2004): 342.

Lukito, Ratno, Hukum Sakral dan Hukum Sekuler: Studi tentang Konflik dan Resolusi dalam Sistem Hukum Indonesia, Jakarta: Alvabet, 2008.

----, Interpersonal Law in Modern Indonesia, Yogyakarta: CLSC, 2007.

----, Legal Pluralism in Indonesia: Bridging the Unbridgeable, New York and 
London: Routledge, forthcoming.

Memon, Kamran, “A Survey of Muslims in the Legal Profession," Journal of Islamic Law and Culture 2 (1997): 121.

Oba, Abdulmumini A., "Lawyers, Legal Education and the Shariah Courts in Nigeria," Journal of Legal Pluralism and Unofficial Law 49 (2004): 113.

Otto, J. M., "Jurists, Nation Building, and Social Tensions in Egypt," in B. Galjart and P. Silva (eds), Designers of Development: Intellectuals and Technocrats in the Third World, Leiden: CNWS, 1995.

Pokja Akademik UIN Sunan Kalijaga, Kompetensi Program Studi Universitas Islam Negeri (UIN) Sunan Kalijaga, Yogyakarta: Pokja Akademik UIN SUKA, 2006.

Porter, Donald J., Managing Politics and Islam in Indonesia, London and New York: Routledge Curzon, 2002.

"Prof. Mardjono: Asal Lulus Ujian, Sarjana Syariah Bisa Jadi Advokat," Hukum Online, 21 October 2002, http://www.hukumonline.com/ detail.asp?id=6696\&cl=Berita, accessed 27th January 2009.

Pye, A. Kenneth. "The Role of Legal Services in the Antipoverty Program," Law and Cotemporary Problems 31,1 (1966): 211.

Sarat, Austin and Stuart A. Scheingold, Cause Lawyers and Social Movements, Stanford, California: Stanford University Press, 2006.

"Tragis, Hanya Tujuh Sarjana Syariah yang Lolos Calon Advokat," Hukum Online, 20 July 2007, http:/ / www.hukumonline.com/ detail. asp?id=17192\&cl=Berita, accessed 12th January 2009.

Trigg, Roger, Religion in Public Life: Must Faith Be Privatized?, Oxford: Oxford University Press, 2007.

Turam, Berna, Between Islam and the State, Stanford, California: Stanford University Press, 2007.

"UU Advokat, Cermin Langkah Mundur," Kompas Online, 10 April 2003, http://www2.kompas.com/kompas-cetak/0304/10/ nasional/249211.htm, accessed 27th January 2009.

\section{Interview}

Interview with a common lawyer, Nur Kholis, November 10, 2009. 
Syariah Advocates' Struggle for Equality in Indonesian Legal Pluralism

Interview with Director of APSI Yogyakarta branch, Budi Ruhiatudin, on December 11, 2009.

Interview with M. Nur Khoirin, the secretary general of APSI, on January 27, 2009.

Interview with Nur Khoirin on January 6, 2010.

Interview with Taufik Ch., on November 28, 2009.

Interview with the Dean of the Faculty of Syariah and Law State Islamic University Sunan Kalijaga Yogyakarta, Yudian Wahyudi, November 15, 2010.

Interview with the secretary general of APSI on January 6, 2009. 
Ratno Lukito 